\author{
Mariusz Mielczarek \\ https://doi.org/10.26485/AAL/2021/67/2
}

\title{
NIKONION IN ROMAN TIMES \\ A FRAGMENT OF HISTORY OF AN ANCIENT CITY ON THE LOWER DNIESTER
}

\begin{abstract}
This article presents settlement during the Roman period upon the territory of the Greek city of Nikonion, which developed on the mouth of the Dniester River from the 6th century BC to the middle of the 3rd century BC. The region was brought into the Roman sphere of interest in the 1st century AD. The middle of the 1st century AD was the time of the repeated settlement of the Greek city. The basis for these speculations are materials obtained during archaeological work carried out by the Archaeological Museum of the Ukrainian Academy of Sciences in Odessa as well as the Institute of Archaeology of the N. Copernicus University in Torun and the Institute of Archaeology and Ethnology of the Polish Academy of Sciences
\end{abstract}

Keywords: Northern Black Sea coast, Nikonion, Roman period, settlement

\section{NIKONION W CZASACH RZYMSKICH \\ FRAGMENT HISTORII ANTYCZNEGO MIASTA NAD DOLNYM DNIESTREM}

\begin{abstract}
ABSTRAKT $\mathrm{W}$ artykule zaprezentowano osadnictwo $\mathrm{z}$ okresu rzymskiego na terenie greckiego miasta Nikonion, rozwijającego się u ujścia Dniestru od VI w. p.n.e. po połowę III w. p.n.e. W strefę zainteresowań Rzymu region ten włączony została w I wieku n.e. Połowa I w. n.e. to czas powtórnego osadnictwa na terenie greckiego miasta. Podstawą rozważań są materiały uzyskane w trakcie prac archeologicznych prowadzonych przez Muzeum Archeologiczne Ukraińskiej Akademii Nauk w Odessie oraz Instytut Archeologii Uniwersytetu M. Kopernika w Toruniu i Instytut Archeologii i Etnologii Polskiej Akademii Nauk
\end{abstract}

Słowa kluczowe: północne wybrzeża Morza Czarnego, Nkonion, okres rzymski, osadnictwo

The north-western part of the Black Sea coast became part of the Roman sphere of influence from the first century AD. ${ }^{1}$ The middle of the same

1 Present article is based on the results of more than 60 years of archaeological research of Nikonion. The last fourteen years of archaeological exploration of Nikonion was carried out by Ukrainian archaeologists from the Archaeological Museum of the Ukrainian National Academy of Sciences at Odessa, and Polish archaeologists from the N. Copernicus University at Torun as well as from the Institute of Archaeology and Ethnology of the Polish Academy of Sciences, Łódź Mielczarek 2017b. On the excavations see Sekerskaâ 1989, and the monograph Ohotnikov 1997 on Greek Nikonion, which is still relevant. On the results of the joint archaeological work, see, for example, one of reports: Sekerskaâ, Mil'čarek [Mielczarek] 2000. I would like yet again thank for their very fruitful cooperation Dr. N.M. Sekerskaâ, Dr. S.B. Ohotnikov and Dr. I.V. Bruâko, the director of Nikonion necropolis century was a period of renewed activity in settlement upon the territory of Greek city Nikonion, which was the most important polis in the region from sixth to the fourth century BC.

Is believed that banks of the present day liman (estuary) of the Dniester River follow the same path of the two branches of the delta of Tyras River, ${ }^{2}$ the ancient Dniester, that existed in Antiquity. ${ }^{3}$ More than 70 settlements related to Greek colonization on the banks of the River Dniester, ${ }^{4}$ have

excavations, also for his kind courtesy to use two drawings from his works.

2 Pliny NH4.82 clarus amnis Tyra. Also Mielczarek 2020.

3 Agbunov 1978:18; Bruâko, Karpov 1992: 93; Dzis-Rajko et al. 2012: 12.

4 It should be noted that at present a 'new model' for the colonization of the North-Western Black Sea coast has been proposed. See Bujskih 2013 on the problem of Istros and Orgame. 


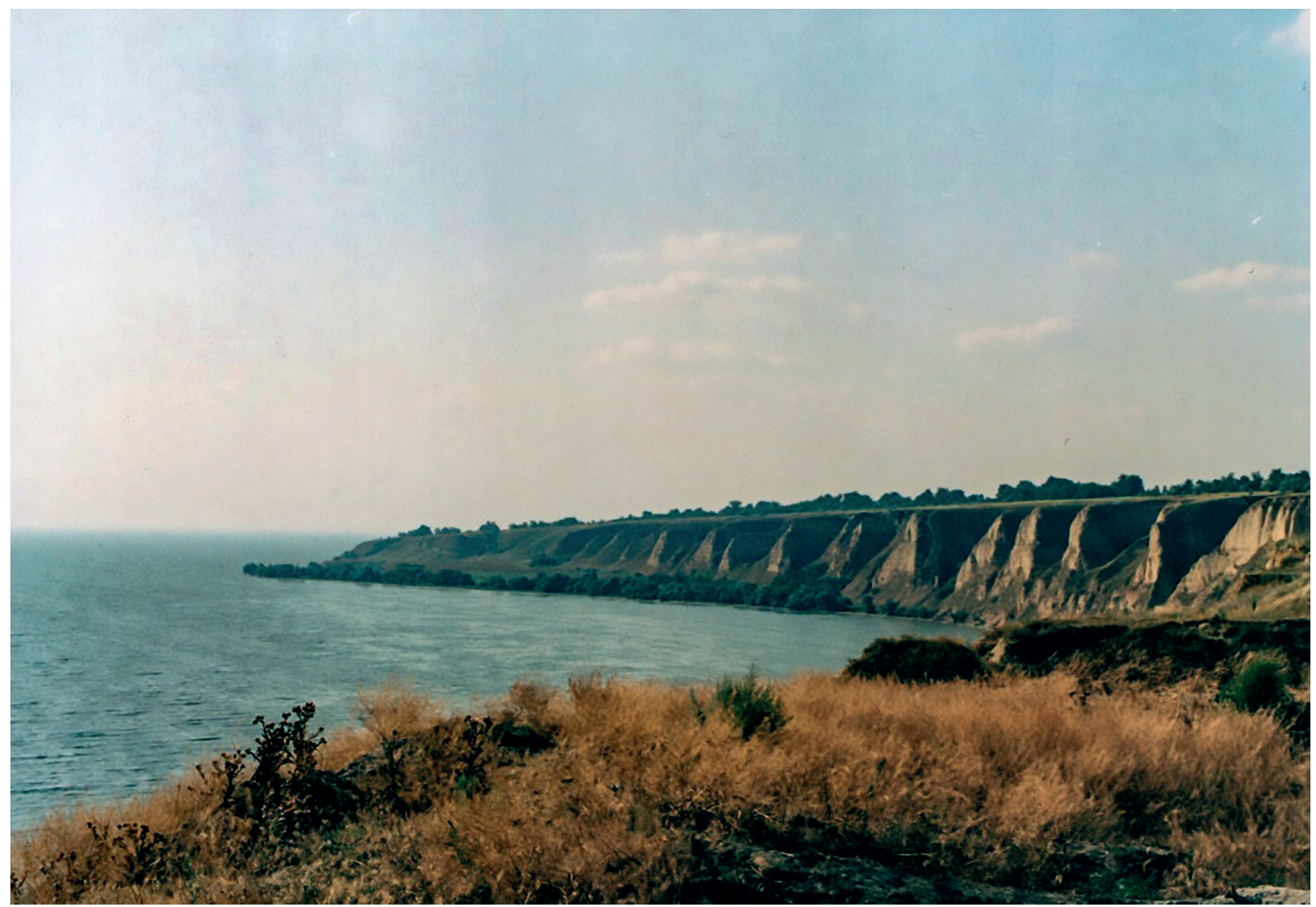

Fig. 1. Photo M. Mielczarek

been identified so far. ${ }^{5}$ Most of them are located on the left bank of the liman. Some of them survived down to the Roman time. A number of them have been explored archaeologically. ${ }^{6}$

Only three cities are indicated in the very scanty ancient literary sources as having been located in the region of Lower Tyras River: Nikonion, Tyras and Ophiussa, all three referred to as poleis. Nikonion ${ }^{7}$ is located on the left bank of the liman (Fig. 1), the polis of Tyras on the right.

5 S.B. Ohotnikov, who has published the basic study on the subject (Ohotnikov 1990), suggests that the number of settlements should be assessed to have been around 100 .

6 For instance, see Dzis-Rajko, Ohotnikov, Redina 2012 on the settlement of the $4^{\text {th }}-3^{\text {rd }}$ century BC.

7 In the text of the inscription discovered at Tyras in 1987, which has been dated to the first quarter of the $3^{\text {rd }}$

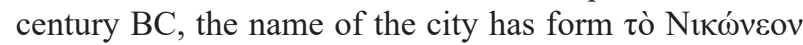
(Vinogradov 1997; Vinogradov 1999). In the opinion of U.G. Vinogradov this is correct name of the city. Strabo

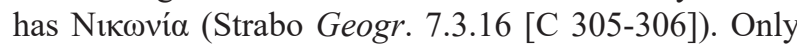
two cities are listed in the text of Strabo, Nikonia and

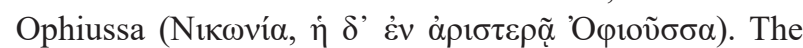

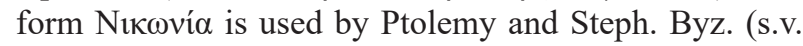

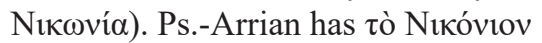

The location of Ophiussa, ${ }^{8}$ mentioned by both Ps.Scylax ${ }^{9}$ as well as by Strabo, ${ }^{10}$ is uncertain. Strabo has indicated that Ophiussa was 'on the left' of Nikonion. ${ }^{11}$ Pliny's view that Ophiussa was an old name for Tyras is now generally accepted. ${ }^{12}$ The problem is that Pliny's sources for his knowledge of the lower Tyras River are not clearly known. Eratosthenes, Artemidoros and Agrippa have been suggested. ${ }^{13}$

8 Agbunov 1979: 128-138; Agbunov 1984: 131-132.

9 Ps.-Scylax 68 (after Counillon 2004). At present there is no reason to change the corrected reading of the manuscript Parisinus 443 proposed by K. Müller. GGM I, Paris 1855.

10 Cf. Roller 2018: 359-360.

11 Strabo, Geogr. 7.3.16. It has even been suggested that Ophiussa was located on an island which has ceased to exist as the water level has changed (Mielczarek 2018).

12 Pliny NH 4.82 clarus amnis Tyra, oppido nomen inponens, ubi antea Ophiusa dicebatur; cf . Val. Flac. 6.84-85.

13 Skržynskaâ 1977: 74-89. 


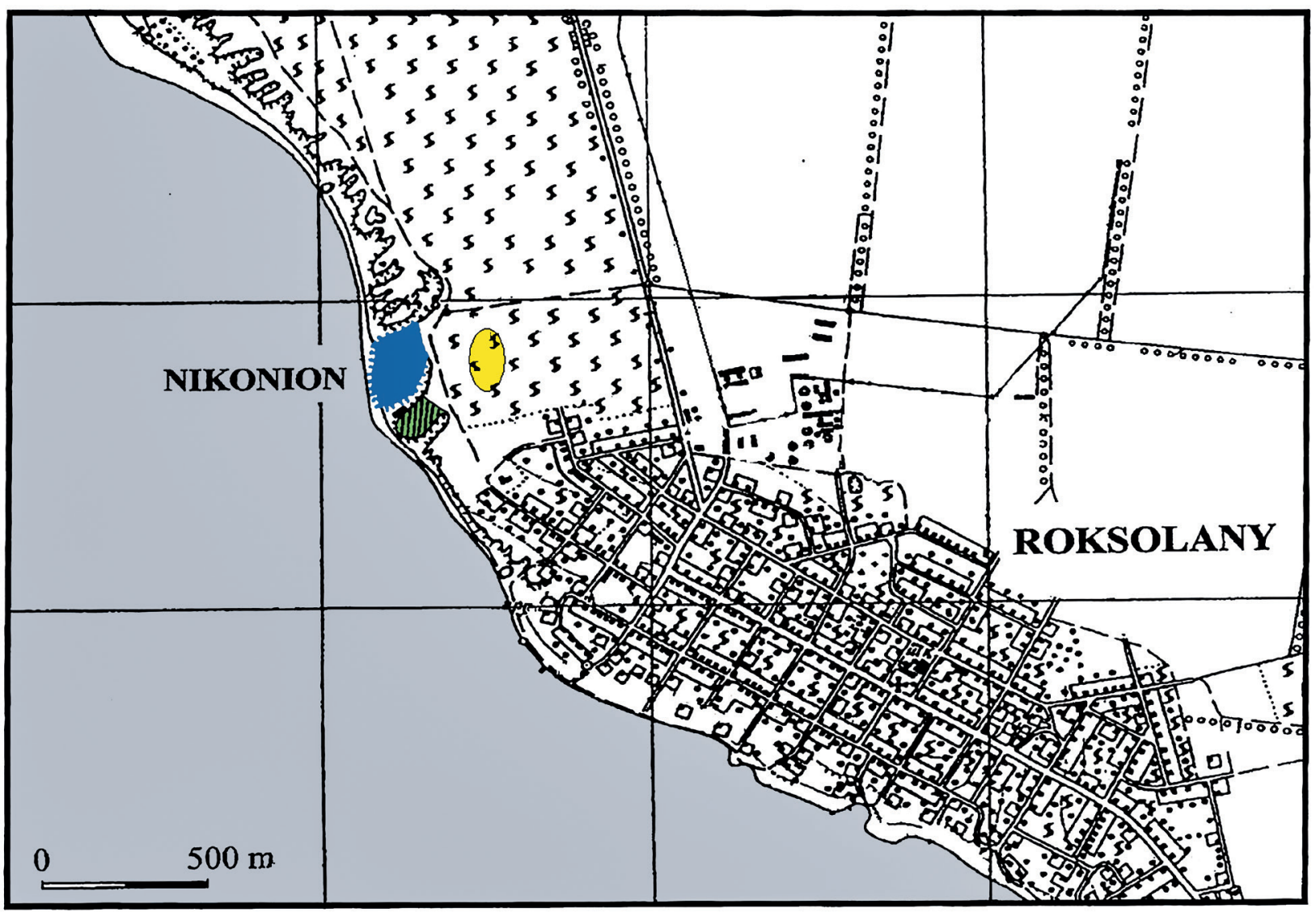

Fig. 2. Drawing E. Wtorkiewicz-Marosik

The mound covering the ancient Nikonion ${ }^{14}$ is located to the north-west of the present-day village Roksolany, south-west of Odessa (Fig. 2, blue colour) ${ }^{15}$ From the north, east and south the mound is bordered by ravines. One part of the ancient city, the so-called 'lower city', was definitively destroyed by the Dniester River in $1904 .{ }^{16}$ We have no means of estimating how big the 'lower city' of Nikonion was. The suggestion that the lost part of the city destroyed by the river was much larger than the preserved part has won general acceptance. ${ }^{17}$ The nature of the finds recovered from the mound covering upper city suggest that the lower city was more probably the administrative and religious centre of the polis.

14 A publication of key importance for the study of the Roksolankoe gorodišče (Roksolanian mound), the ancient Nikonion, is Karyškovskij 1966.

15 Proof of the location of the 'settlement' proposed by M.S. Sinicyn were, and are still, treated as questionable (Karyshkovskii, Kleiman 1985: 15-16).

16 Goškevič 1912: 176.

17 Two underwater excavations ended in failure, as the layer of silt in the liman is very thick. Bruâko, Dzigovskij, Sekerskaâ 2008: 10-11.
The oldest ceramics found during excavations on Nikonion indicate that the city was founded in the middle of the sixth century BC or earlier. ${ }^{18}$ The idea that Miletus was the metropolis of Nikonion has been questioned. Over time it was recognized that coins of Istros, together with local imitations of the cast bronze coins of Istros found on the territory of Nikonion, suggested a special and strong relationship with Istros. ${ }^{19}$ The suggestion that Nikonion was an emporion of Istros has been proposed. ${ }^{20}$ The inscription, dating to the third century BC, honouring Authocles discovered in Tyras, gave significant support to the idea that Istros could be the founder of Nikonion. ${ }^{21}$ On the other hand is not clear whether Istros had sufficient potential to found a new city. ${ }^{22}$

18 Sekers'ka, Bujs'kih 2018: 37-44; Sekerskaâ, Bujskih 2019: 203-212.

19 For a discussion of the cast bronze coins with the name of Scyles (omitting Herodotus 4.78-80) see, among others, Vinogradov 1989: 116; Zaginajlo, Karyškovskij 1990: 3-15, Mielczarek 2005.

20 Sinicyn 1966: 55; Musielak 2003: 30.

21 Vinogradov 1999.

22 In discussing problems surrounding the origins of Nikonion is interesting to refer to an idea propagated 


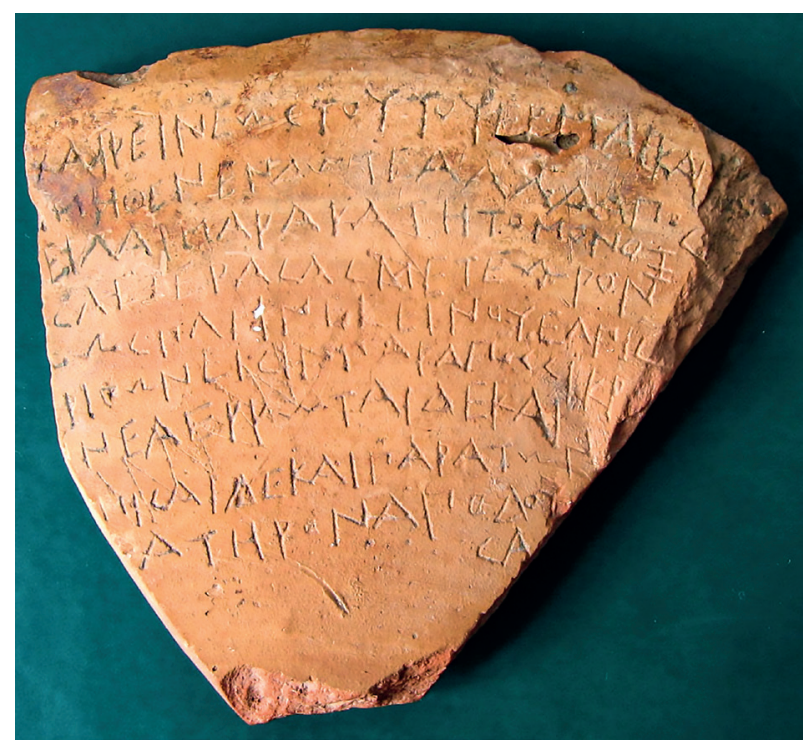

Fig. 3. Courtesy of I. Głuszek

The epigraphic evidence found at Nikonion during the course of archaeological excavations is limited to a fragment (four letters) of an inscription, and graffiti (Fig. 3). ${ }^{23}$ Nikonion dominated the region from the sixth to the fourth centuries BC. The opinion that all the settlements located on the left bank of Dniester liman should be regarded as belonging to the chora of Nikonion is widely accepted. ${ }^{24}$

Houses dug into the ground were predominant at Nikonion from the sixth century BC to the first quarter of the fifth century. ${ }^{25}$ The fifth and fourth centuries $\mathrm{BC}$ are a period of prosperity for Nikonion, and the period of the greatest building activity at the city, built mostly of well-finished stones, as revealed in the deep cellars (Fig. 4). Clay bricks were also used. The necropolis which served the city of Nikonion during the sixth to the fourth centuries BC has not been identified. Only individual separate graves have been found.

by A.S. Rusâeva. In her opinion the late chronology of the Greek settlement on the Lower Tyras region was connected with wars of Cyrus. Rusâeva 1997: 145. In any discussion of the origins of Nikonion the problem of Orgame should be taken into account.

23 Awianowicz 2009. From the rich older literature on the subject see Sekerskij 1976; Sekerskaâ, Sekerskij 1997.

24 The opinion that the left branch of Tyras River delta was more navigable than a right branch in those times is widely accepted. It is worth noting that the condition of the soil of the liman are similar on both sides of the Dniester. Is very possible that this opinion holds true also for ancient times (Odrin 2005: 4-5, 14-20).

25 Hdt. 4.78-80. Mielczarek 2016.
In the last quarter of the fourth century $\mathrm{BC}$, the city was burned. This occurrence is usually associated with the expedition of Zopyrion in $331 \mathrm{BC}$, which reached the city walls of Olbia. ${ }^{26}$ During the succeeding period Nikonion, as other settlements of the region, experienced an acute crisis. From the end of the third century life in Nikonion practically ceases to exist.

The polis of Tyras played the leading role in the region downstream of the Tyras River in the second half of the third century BC. ${ }^{27}$ The domination of Tyras continued into the Roman period. ${ }^{28}$ Tyras, when it was incorporated into the Roman empire, was defined in law as a civitas libera et immunis. Tyras continued to existed into Late Antiquity and even beyond. ${ }^{29}$

The Roman period is a time of rebirth at Nikonion, with a new shape to the city and with a new population. Even if the history of ancient Nikonion in Roman times is incomplete (the idea that the former name of the city was still in use is based on textual evidence, ${ }^{30}$ the rebirth of the city is a very interesting phenomenon. The Nikonion of Roman times is interesting because it can throw light on the position of Tyras in the changes in settlement on the Lower Dniester region, which is an important problem. Our knowledge about Roman Nikonion is based solely on archaeological evidence, and the archaeological materials relevant to Roman times are much poorer than these which can be dated to the Greek period of the city.

The opinion proposed by M.S. Sinitsyn, the excavator of Nikonion between 1956 and 1966, that during the first centuries AD settlements spread out to the small plateau lying south of mound covering Greek Nikonion, to the so called Nikonij Mys, was popular for many years (Fig. 2, green). ${ }^{31}$ Currently, as a result of recent archaeological work, it is certain that the Roman remains of Nikonion are only

26 Just. 12.2.16; Macr., Sat.1.11.33. See Vinogradov 1989: 153-164.

27 For instance Eux. (Ps.-Arr.) 62.

28 See from rich literature on the subject see Sarnowski 1988; Son 1993: 12-20.

29 The city developed in the mediaeval ages as Asprokastron, and as Akkerman in the Ottoman Empire. Belgorod Dnestrovskij, to give the city its modern name, has played an important role in the route 'from the Black Sea to the Baltic' (Mielczarek 2017a).

30 A problem is the identification of the name Nikonion on the 'map' on the shield from Dura Europos (Zahariade 1975; Ohotnikov 1997: 89. Cf. Bruâko, Dzigovskij, Sekerskaâ 2008: 184).

31 Bruâko, Dzigovskij, Sekerskaâ 2008: 188. 


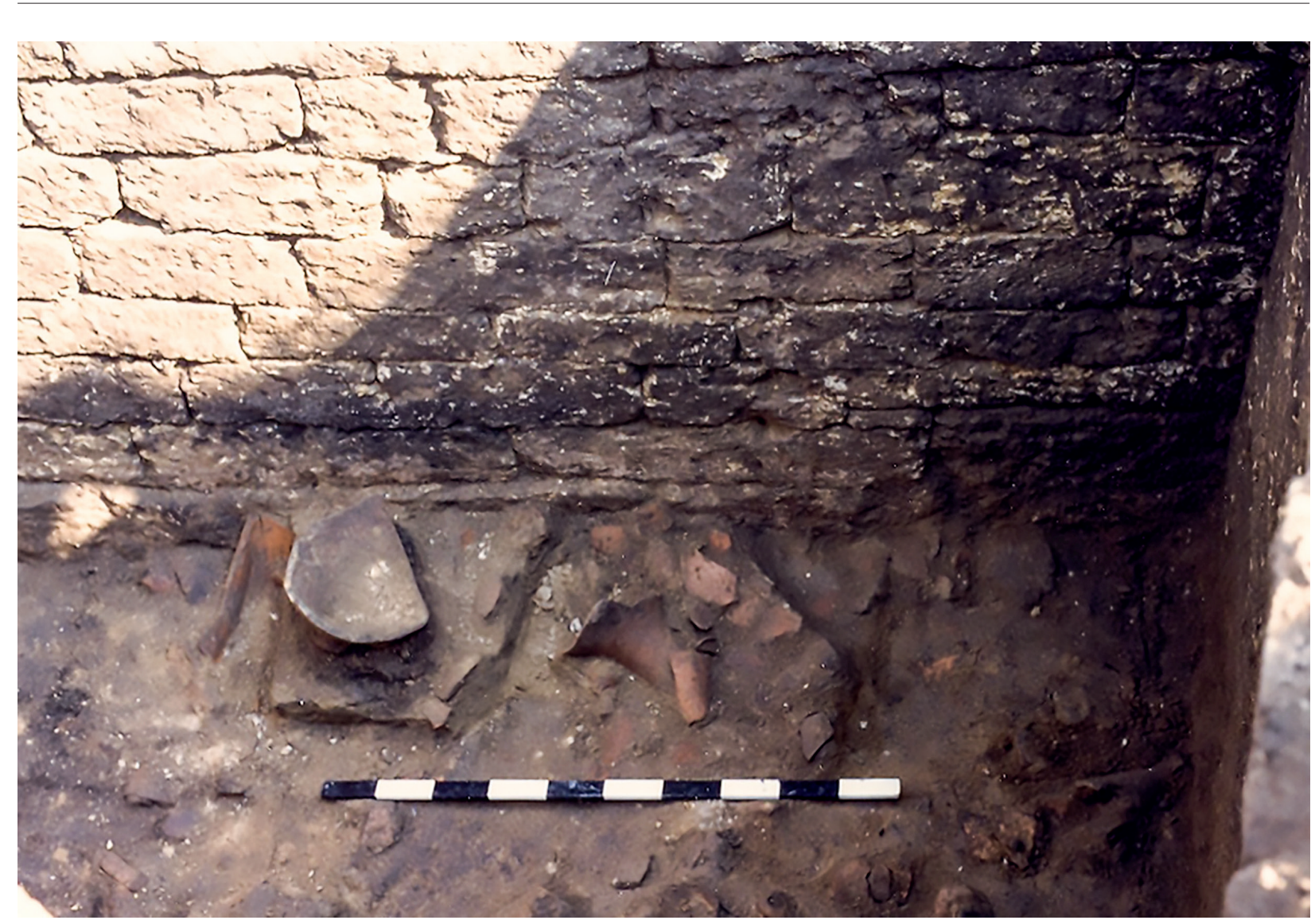

Fig. 4 . Photo M. Mielczarek

around $80 \mathrm{~cm}$ below present surface of the mound covering Greek city. Consequently, the remains of Roman city have been severely damaged, especially as a result of the deep ploughing recently carried out to establish vines.

Remains of houses dating to the Roman period have survived in different parts of the mound, mainly fragments of walls, although no complete house has been discovered. ${ }^{32}$ The house with two rooms excavated by M.S. Sinitsyn consisted of a wall dividing two rooms which was $7 \mathrm{~m}$ long. The width of walls was between 0,4 and $0,5 \mathrm{~m}$. Walls with a width of $0,6 \mathrm{~m}$ are rare. In one room a hearth constructed in clay was found. It is possible that the house comprised three rooms..$^{33}$ Is possible that the house had an area ca. $105 \mathrm{~m}^{2}$.

In the 'central trench'34 of the mound fragments of two walls of a house, dating to the second to fourth centuries $\mathrm{AD}$ were discovered. ${ }^{35}$ Cavities built in clay, with stones in their upper part, were

32 Bruâko, Dzigovskij, Sekerskaâ 2008: 17 Fig. 5, 22.

33 Bruâko, Dzigovskij, Sekerskaâ 2008: 23.

34 Kuz'menko 1976.

35 Kuz'menko 1976; Bruâko, Dzigovskij, Sekerskaā 2008: 23-25. located in the rooms. In some of them fragments of ceramics, as well as small clay figurines, were found. One room in the house measured ca. $20 \mathrm{~m}^{2}$; but only fragments of two walls have survived. One of them, $4 \mathrm{~m}$ long, was built of three courses of unfinished stone surviving up to a height of $60 \mathrm{~cm}$.

Houses were built only to a small extent using stone. Stones from older constructions were also used which were not finished as they were formerly used in Greek cellars (Fig. 4). The remains of buildings are marked by clusters of stones (Fig. 5). In the first centuries AD they are mostly constructions consisting of two or more rooms (Fig. 6). Walls were constructed from clay walls placed on stone foundation. Some of these stones have been reused from older, Greek, constructions.

The typical inventory of the houses is poor, ${ }^{36}$ but this is important evidence for the problem of the relations, above all economic, that the city enjoyed with the outside world.

It is only natural that ceramics should dominate among finds. ${ }^{37}$ Amphoras of the second and third

36 Morozova 1997.

37 A significant number of the ceramics, above all found in fragments, dating to the Roman period were 


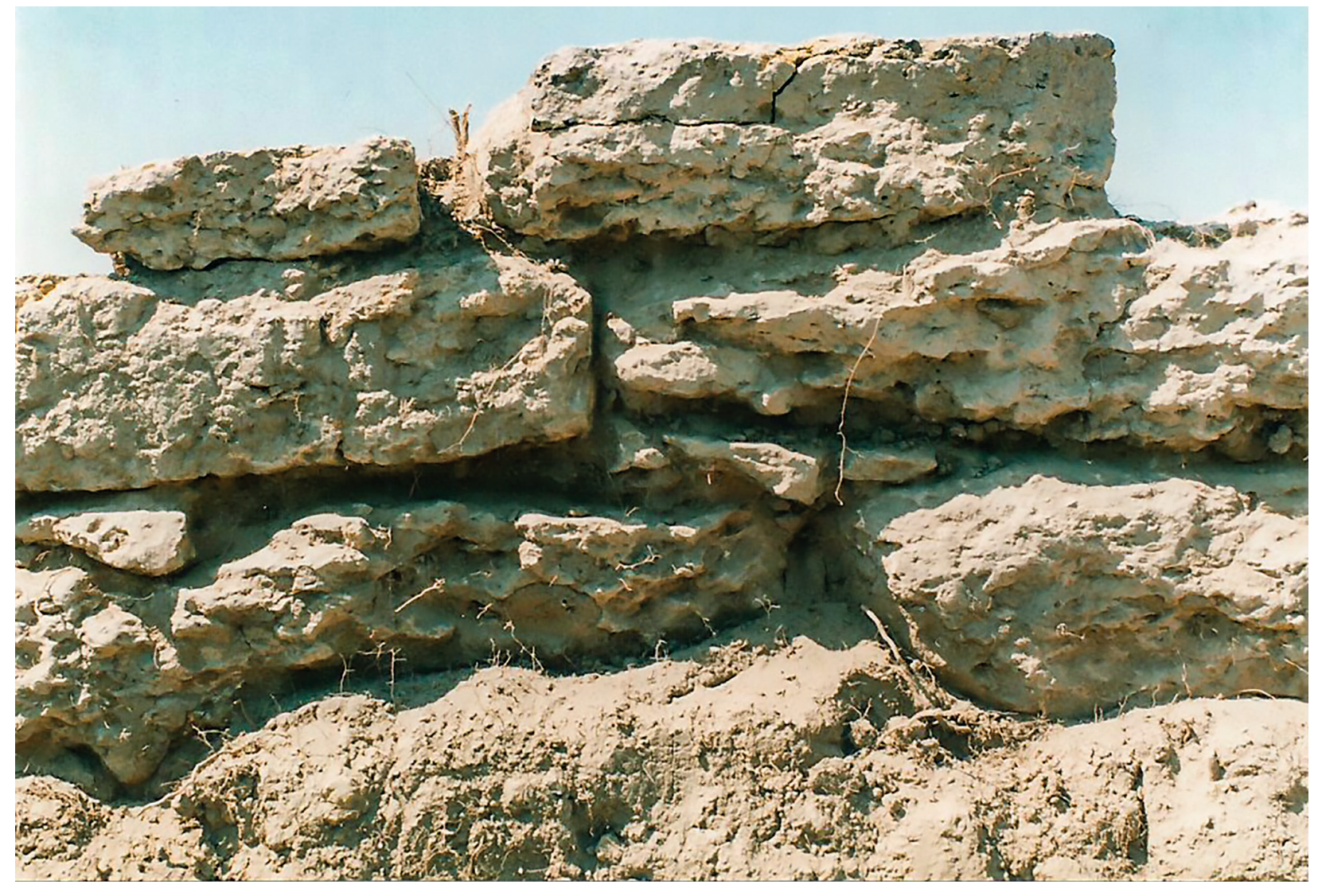

Fig. 5. Photo M. Mielczarek

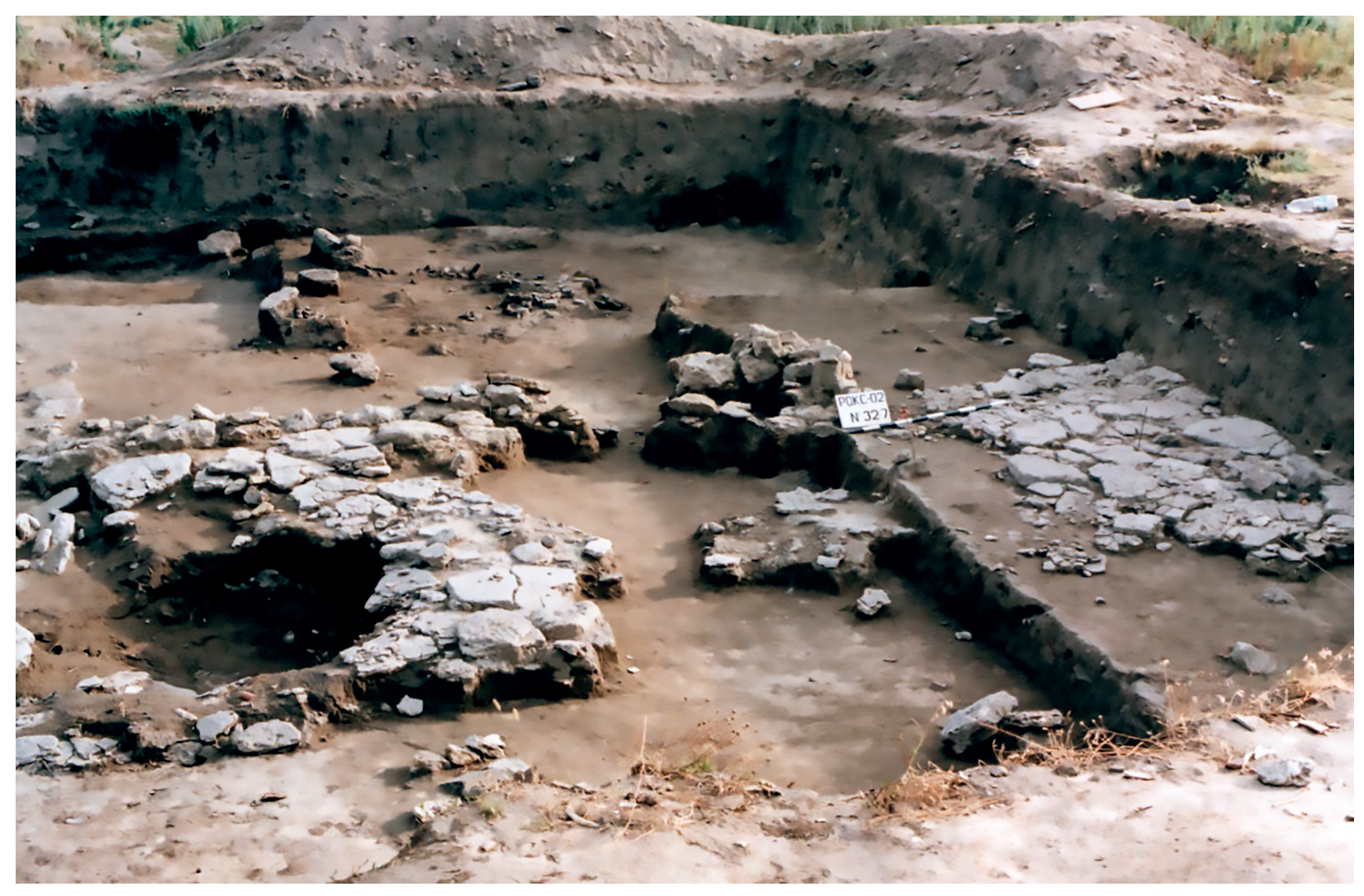

Fig. 6. Photo M. Mielczarek 


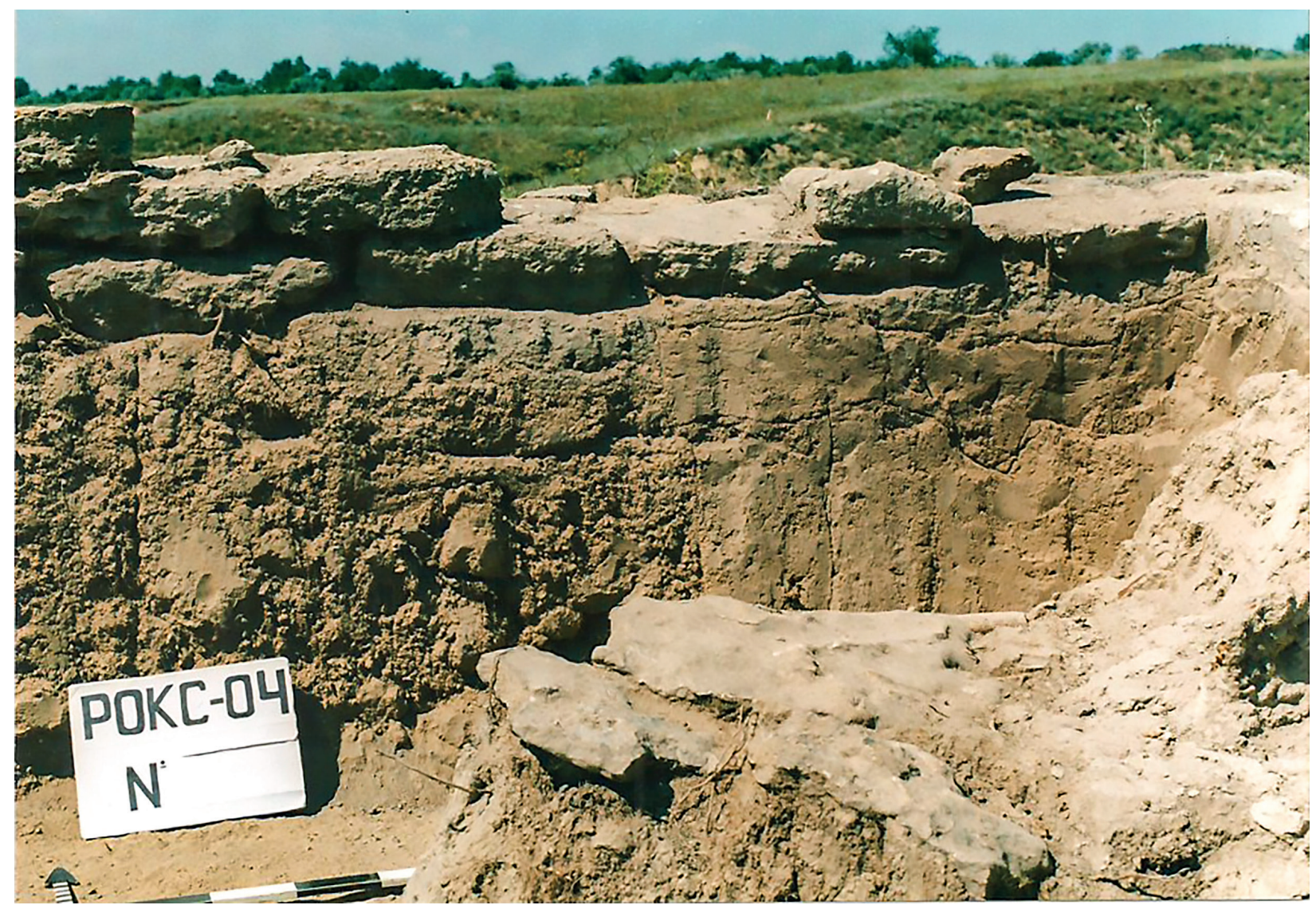

Fig. 7. Photo M. Mielczarek

centuries AD are heavily represented. Amphoras produced in Panticapaeum and Mirmekion are the most popular. Such amphoras are the most popular in the north Black See region in the 2nd and 3rd centuries AD. ${ }^{38}$ These inventories are very informative about the trading connections of the citizens of Roman Nikonion. The amphorae found at Nikonion are the same type as those discovered in Olbia or the Bosporan cities Tiritake or Nymphaion. ${ }^{39}$ The same situation is noted in relation to red-slip ware.

Basing his opinion on the results of the first years of excavation, M.S. Sinitsyn suggested that the city was devoid of defensive walls. Only fragments of a ditch dug into the ground were identified. ${ }^{40}$

Remains of the defensive wall of the city ${ }^{41}$ were discovered in the north-eastern part of the

found in mixed assemblages with materials dated from the $6^{\text {th }}$ century $\mathrm{BC}$ to $3^{\text {rd }}$ century AD.

38 Bruâko, Dzigovskij, Sekerskaâ 2008: 29-34.

39 Morozova 1997: 69.

40 Sinicyn 1966 (see also Sinicyn 1960); Bruâko, Dzigovskij, Sekerskaâ 2008: 16-22.

${ }^{41}$ According to the first excavator of Nikonion, M.S. Sinitsyn the constroction was not to be treated as a defensive wall. mound in 1961. It was constructed of well finished stones $6,75 \mathrm{~m}$ long and $1 \mathrm{~m}$ wide, and consisting of three courses of stones preserved up to a height of $0,4 \mathrm{~m}$. However in the opinion of M.S. Sinitsyn this section of wall constructed with well-finished stones did not form part of the defence system of the city. A second fragment was excavated in 1987 and 1990. Fragments of wall were discovered at the northern part of the mound. After these excavations it is certain that Roman Nikonion had a defence wall. Some years later small fragment of the defence wall constructed from stones was discovered. A control excavation (Fig. 7) confirmed that we are dealing with the defensive wall of Roman times. The town was defended by a wall and trench dug in front of it.

Handmade clay ceramics (above all pots) decorated, mostly with fingerprints, are the most popular. The situation is typical for all Late Scythian settlements. Late Scythians settled on the mound after their migration from the Crimea. ${ }^{42}$

The most important find contributing to our knowledge of the city in Roman times was the discovery in 1991 of a necropolis dating to the first

42 Bruâko, Dzigovskij, Sekerskaâ 2008: 180. 


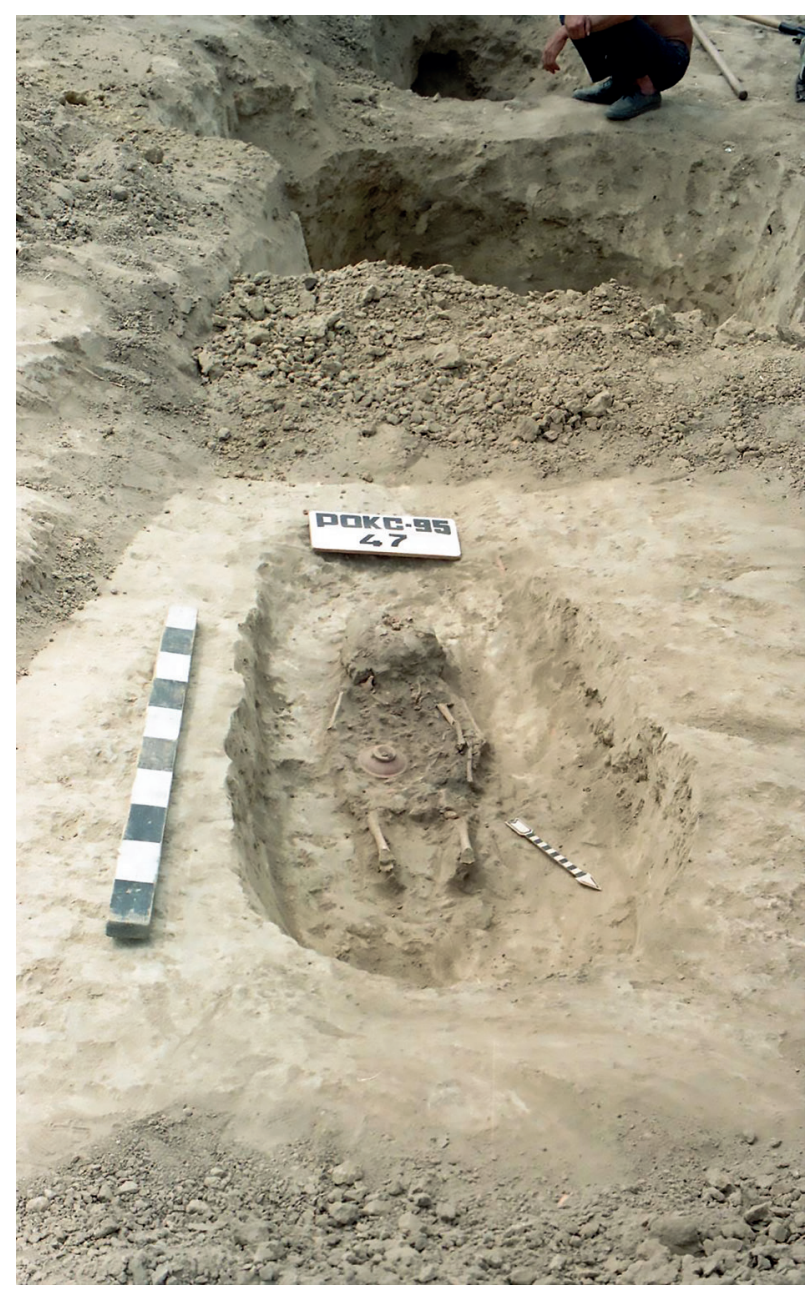

Fig. 8. Courtesy of I. Bruako

three centuries AD (Fig. 2, yellow). Almost all of the tombs were looted. The excavation of the necropolis has not been completed. ${ }^{43}$ The Roman necropolis consists of 45 burials. Among the graves belonging to the Roman period were 18 subterranean tombs with collective burials.

Interesting is that on the area of Roman time necropolis were also located early mediaeval tombs (Fig. 8).

The typical type of burial of the Roman period in the necropolis is in a subterranean tomb dug into the clay soil. The construction of the tombs is specific: a long corridor, forming a kind of dromos, with steps leads to the burial chamber (Figs. 9 and 10), 4 to $5 \mathrm{~m}$ below present surface. The burial chamber is closed off with a stone slab.

The tomb furniture consists of pottery, including red-slip. Among the latter, specimens from

43 The excavations of the necropolis was made under direction of Dr. I.V. Bruâko. See Bruâko, Dzigovskij, Sekerskaâ 2008, 15.

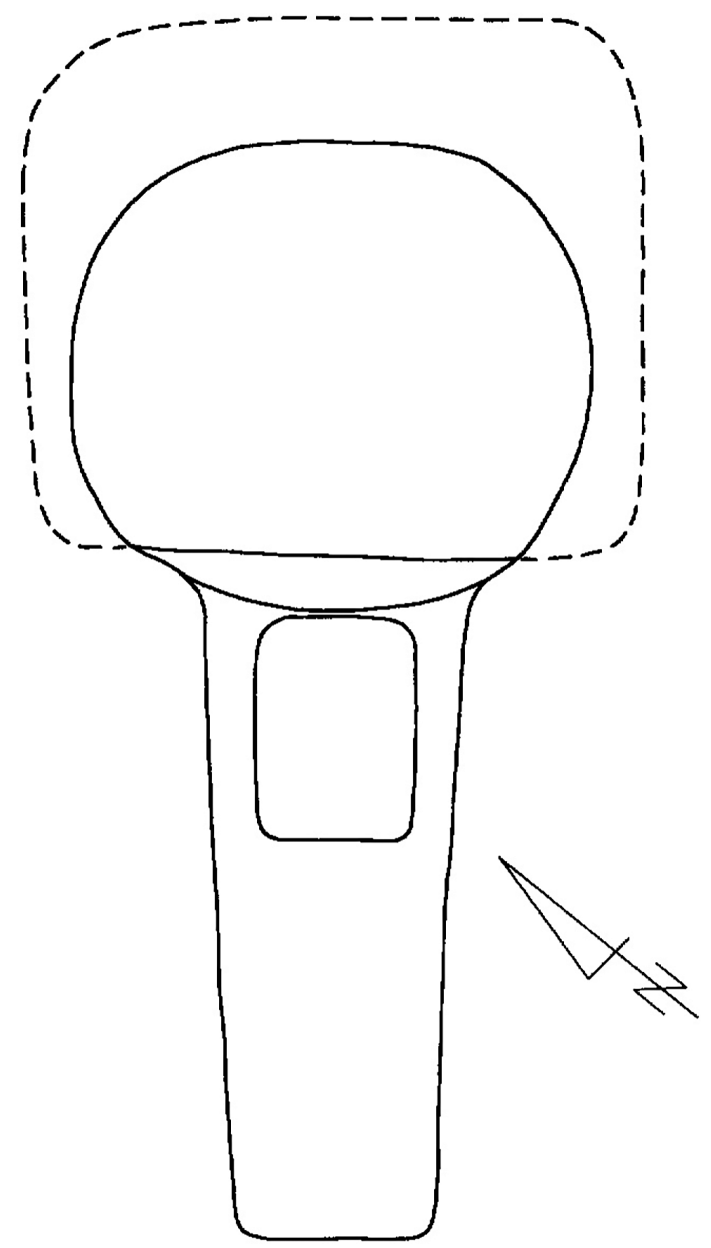

Fig. 9. Courtesy of I. Bruako. Drawing E. Wtorkiewicz-Marosik

workshops in Asia Minor dominate ${ }^{44}$ Handmade clay wares (above all pots), glass bowls, bronze bells are also found. Personal jewellery, including silver fibulae as well as two gems (one object, with a standing figure of Demeter was found in a tomb, the second was found on the surface in the area of necropolis). ${ }^{45}$ It was a popular custom to place coins as a part of the funeral inventory. Among the coins one aureus was discovered. The rich inventory of tombs on the necropolis of Nikonion seems to result from the close connections the site enjoyed with Tyras.

Animal skeletons were also found. Horse skeletons dominate (Fig. 11).

Among the coins dating to the first centuries $\mathrm{AD}$ are coins of Tyras, and Roman coins from the Balkan Peninsula, as well as from Asia Minor. Coins of Tyras are most numerous. A hoard of ca. 30 coins of Tyras dating to the end of second and the beginnings of the third centuries was found. More precise data are unknown.

44 This opinion is based on Bruyako 1997.

45 Bruâko, Ostroverkhov 1997. 


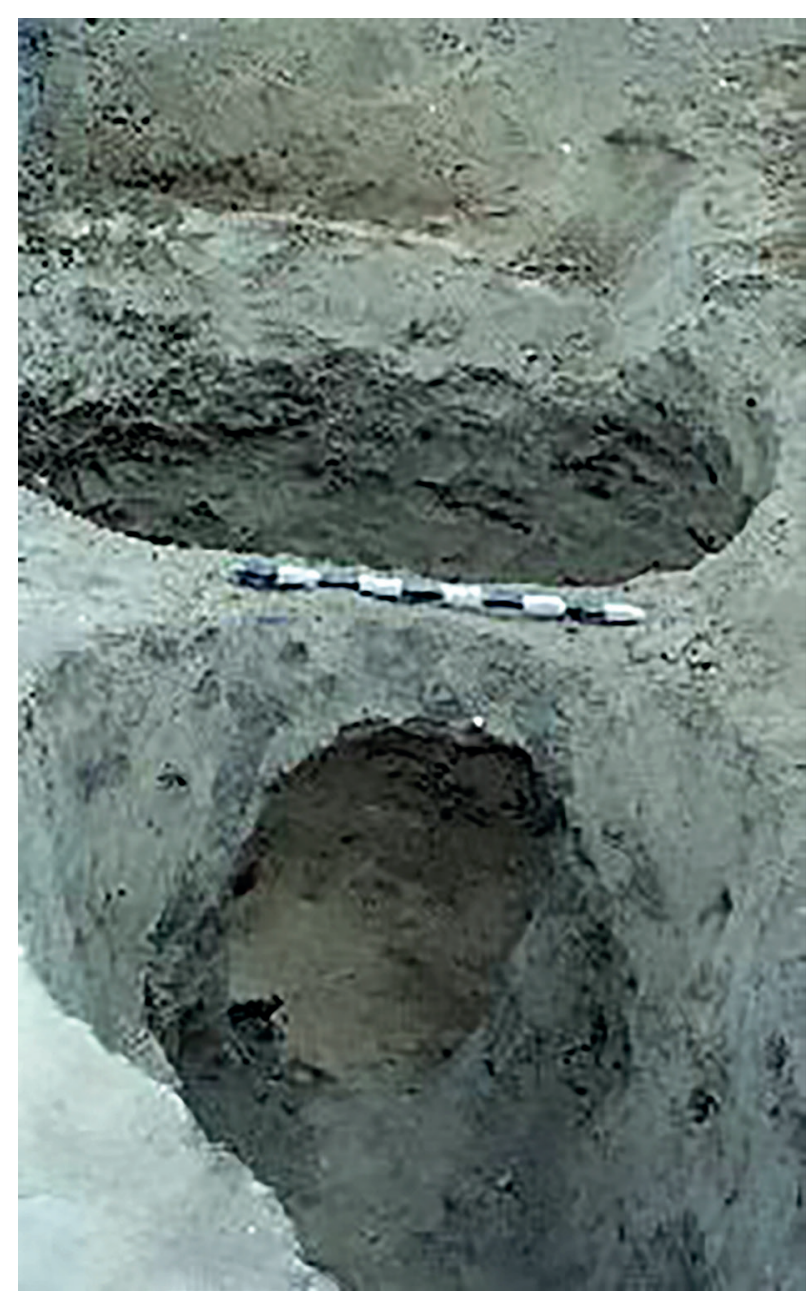

Fig. 10. Photo M. Mielczarek

In the course of archaeological excavations a denarius of Marcus Aurelius dating to 163 has been found, as well as an antoninianus of Philip the Arab (244-249). Single finds of coins struck by Commodus (180-192), Septimius Severus (193211) have been also noted.

Interesting is that among coins found in Roman necropolis are bronze coins of Histria, which are characteristic for Greek Nikonion. ${ }^{46}$

The main change in the case of Nikonion was a change of inhabitants. In the Roman period the city was inhabited by the Late Scythians, which have arrived from Crimea. Some evidence of Sarmatian influence in the city of Roman time has been also noted. ${ }^{47}$

46 Bruâko, Dzigovskij, Sekerskaâ 2008: 187.

47 Bruâko, Dzigovskij, Sekerskaâ 2008: 182.
Bibliography

Agbunov, M.V. 1978. K voprosu o lokalizacii bašni Neoptolema i Germonaktovoj derevni, VDI 1978, 1: 112-123

Agbunov M.V. 1979. Zametki po antičnoj geografii Nižnego Podnestrov'â, VDI 1979, 2: 118-128

Agbunov M.V. 1984. Materialy po antičnoj geografii Pričernomor'â, VDI 1984, 4: 124-141

Awianowicz, B. 2009: A Hellenistic ostracon from Nikonion, ZPE 2009, 168: 196-198

Bruâko I.V. 1997. The necropolis of Nikonion, (in:) Nikonion 1997: 27-35

Bruâko, I.V., Ostroverkhov A.S. 1997. Gemmy iz nekropolâ Nikoniâ rimskogo vremeni, (in:) Nikonij i antičnyj mir Severnogo Pričernomor'â, Odessa 1997: 76-80

Bruâko, I.V. \& Karpov, V.A. 1992, Drevnââ gografiâ i kolebaniâ urovnâ morâ (Na primere severo-zapadnoj časti Černomorskogo basseina v antičnuû epohu), VDI 1992, 2: 87-97

Bruâko, I.V., Dzigovskij, N.. Sekerskaâ, N.M. 2008. Nikonij rimskoj epohi, Odessa 2008

Bruâko, I.V., Sekerskaâ, E.P. 2016. Očerki ekonomiki naseleniâ Severo-Zapadnogo Pričernomor'â v antičnuû epohu, Odessa 2016

Bujskih A.V. 2013. O grečeskoj kolonizacii Severo-Zapadnogo Pričernomor'â (Novaya Model'?), VDI 2016, 1, 21-39

Counillon, P. 2004. Pseudo-Skylax: Texte, traduction, commentaire philologique et historique, Bordeaux 2004

Dzis-Rajko G.A., Ohotnikov S.B., Redina E.F. 2012. Gorodišče Nadlimanskoe IV-III vv. do n.e. v Nižnem Podnestrov'e, Odessa 2012

Gudkova A.V., Bruâko I.V. 1997. Lepnaâ keramika rimskogo vremeni iz Nikoniâ, (in:) Nikonij i antičnyj mir Severnogo Pričernomor'â, Odessa 1997,72-76

Karyškovskij P.O. 1966. K voprosu o drevnem nazvanii Roksolanskogo gorodišča, MASP 5, 1966, 149-162

Karyškovskij P.O. and Klejman I.B. 1985. Drevnij gorod Tira. Istoriko-arheologičeskij očerk, Kiev 1966

Kuz'menko V.I. 1976. Issledovaniâ rimskih sloev Nikoniâ, MASP 5, 1976, 218-224

Mielczarek M. 2005. Coinage of Nikonion. Greek bronze cast coins between Istrus and Olbia (in:) C. Alfaro, C. Marcos, P. Otero (eds.) XII Congreso Internacional de Numismática. Madrid - 2003. Actas - Proceedings - Actes I, 2005, 273-276 


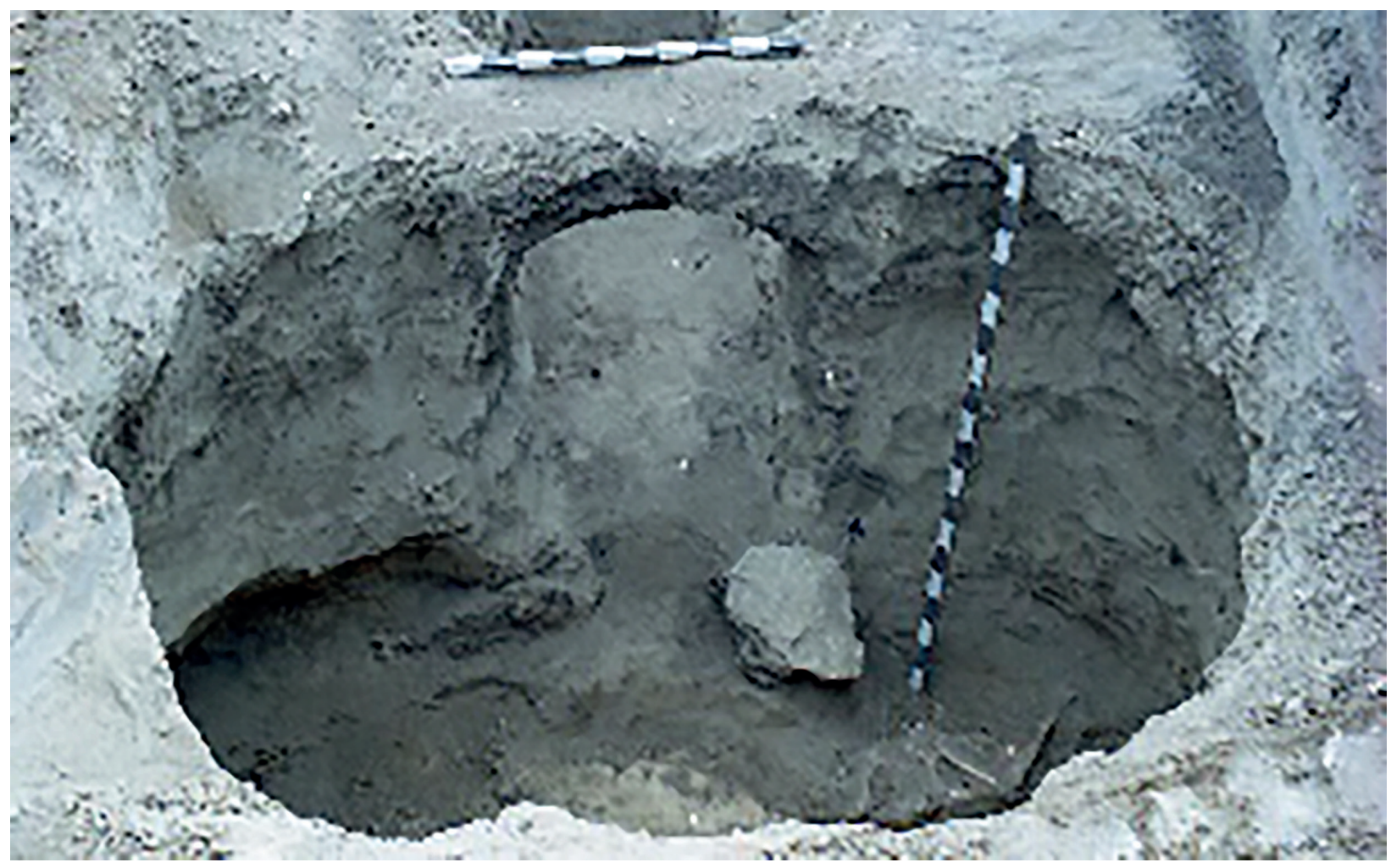

Fig. 11. Photo M. Mielczarek

Mielczarek M. 2016. Houses dug into the ground in Ancient Nikonion in the Lower Dniester region, FAH 2005, 29, 83-92

Mielczarek M. 2017a. ,.... wie ein Schuss vom Dnister bis an das alte Preußen...". Jan Konrad Graf von Zatuskis Hinweise für Jan Nepomucen Sadowski auf der "Suche" nach den Handelsstraßen der Griechen und Römer bis an die Gestade des Baltischen Meeres, (in:) Andrzejowski J., von CarnapBornheim C., Cieśliński A, Kontny B. (eds.), Orbis Barbarorum, Studia ad archaeologiam Germanorum et Baltorum temporibus imperii romani pertinientia Adalberto Nowakowski dedicata [Monumenta Archaeologica Barbarica, seria gemina VI], WarszawaSchleswig, 645-652

Mielczarek M. 2017b. The Lower Dniester Region in Antiquity. History and the Present State of Polish Archaeological Research, (in:) Matera M., Karasiewicz-Szczypioski R. (eds.), The Crimea and the Northern Blak Sea Coast in Archaeological Research 1956-2013, Warsaw, 181-192

Mielczarek M. 2018. Nikonion w opisie Strabona, AAL 64, 129-136

Mielczarek M. 2020. Herodotus and Greek Settlements in the Lower Dniester Region, AAL, 60, 143-148
Morozova Ja. I. 1997. Raskopki verhnego gorizonta Nikoniâ v 1996 godu, (in:) Nikonij i antičnyj mir Severnogo Pričernomor'â, Odessa, 65-71

Musielak M. 2003. Społeczeństwo greckich miast zachodnich wybrzeży Morza Czarnego, Poznań

Nikonion. An Ancient City on the Lower Dniester 1997. M. Mielczarek, S.B. Okhotnikov, N.V. Sekunda (eds.), Toruń 1997

Ochotnikov S.B. [Ohotnikov] 1997, Tyras i Nikonion. Świat kolonii greckich u ujścia Dniestru, Toruń

Odrin O. 2005. Prirodni resursi ta torgovel'no-ekonomičnii potencial antičnih deržav Pivničnogo Pričornomor'â, Nižne Podnistrov'â ta Nižne Pobužâ. Kiiv

Ohotnikov S.B. 1990. Nižnee Podnestrove v VI-V vv. do n.e., Kiev

Ohotnikov S.B. 1997. Fenomen Nikoniâ, (in:) Nikonij i antičnyj mir Severnogo Pričernomor'â, Odessa, 27-32

Sarnowski T. 1988. Wojsko rzymskie w Mezji Dolnej i na północnym wybrzeżu Morza Czarnego, Novaensia 3, Warszawa

Sekerskaâ N.M. 1978. Pogrebeniâ pervyh vekov našej ery iz Nikoniâ, (in:) Arheologičeskie issledovaniâSevero-ZapadnogoPričernomorâ, Kiev

Sekerskaâ N.M. 1989. Antičnyj Nikonij i ego okruga VI-IV vv. do n.e., Kiev 1989 
Sekerskaâ N.M., Sekerskij P.M. 1997. Grafiti $\mathrm{s}$ posvâščsheniem Zevsu iz Nikoniâ, (in:) Nikonij i antičnyj mir Severnogo Pričernomor'â,, Odessa, 44-47

Sekerskaâ N.M., Bujs'kih A.V. 2018. Pro čas zasnuvannâ Nikoniâ (za materialami shidnogrec'koj keramiki, "Arheologiâ" [Kiev] 2018, 1, 37-44

Sekerskaâ N.M., Bujskih A.V. 2019. Rannaâ raspisnaâ keramika iz Nikoniâ, Materiali z Arheologij Pivničnogo Pričornomor'â, Odesa 2019, 203-212

Sekerskaâ N.M., Mil'čarek [Mielczarek] M. 2001. Raboty Nikonijskoj ekspedicii v 2000 g., (in:) Arheologični vidkrittâ Ukraini 1999-2000 rr., Kiiv 2001, 215-216

Sekerskij P.M. 1976. Zastol'naâ nadpis' iz Nikoniâ, MASP 8, 1976, 215-218

Sinicyn M.S. 1960. Raskopki Nadlimanskogo i Roksolanskogo gorodišč v 1957-1958 gg., ZOAO, 1, 189-201

Sinicyn M.S. 1966. Raskopki gorodišča vozle s. Roksolany belâevskogo raiona odesskoj oblasti v 1957-1961 gg., MASP 1966, 5, 5-56

Skrzhinskaâ M.V. 1977. Severnoe Pričernomor'e v opisanii Pliniâ Staršego, Kiev

Son N.A. 1993. Tira rimskogo vremeni, Kiev

Vinogradov, Û.G. 1989. Političeskaâ istoriâ Ol'vijskogo polisa VII-I vv. do n.e., Moskva

Vinogradov, Û.G. 1997. Sinojkizm Nikoniâ, (in:) Nikonij $i$ antičnyj mir Severnogo Pričernomor'â, Odessa, 54-55

Vinogradov, Ju.G. 1999. Istrija, Tira i Nikonij, pokinutyj i vozroždennyj, NiE 16, 50-71

Zachariade M.M. 1975. Noi consideratii istorice asupra scutului de la Dura-Europos, SCIVA 26, 4, 506-520

Zaginailo A.G., Karyškovskij P.O. 1990. Monety skifskogo carâ Skila, (in:) Numizmatičeske issledovaniâ po istorii Ûgo-Vostočnoj Evropy, Kišinev, Štiinica, 3-15
Zaginailo A.G., Sekerskaya N.M. 1997. Ancient Nikonion in the light of 40 years of archaeological excavation (1957-1997), (in:) Nikonion, Toruń 1997, 18-26.

Zubarev V.G. 1999. „Geographičeskoe rukovodstvo" Klavdiâ Ptolemeâ kak istočnik po antičnoj geografii Severnogo Pričernomor'ja, (in:) Podosinov A.V. (ed.), Drevneiše gosudarstva vostočnoj Evropy 1996-1997 gg. Severnoe Pričernomor'e v antičnosti. Voprosy istočnikovedeniâ, Moskva 1999, 316-335.

Zubarev V.G. 2005. Istoričeskaâ geografâ Severnogo Pričernomor'â po danym pismennoj tradicii, Moskva

$A A L$ - Acta Archaeologica Lodziensia, Łódź

FAH - Fasciculi Archaeologiae Historicae, Łódź

$M A S P$ - Materialy po Arheologii Severnogo Pročernomor'â, Odesa, Kiev

NiE $\quad$ - Numizmatika i Epigrafika, Moskva

SCIVA - Studii şi Cercetarii de Istorie Veche şi Archeologie, Bucuresti

VDI - Vestnik Drevnej Istorii, Moskva

$Z O A O$ - Zapiski Odesskogo Arheologičeskogo Obščestva, Odessa

ZPE - Zeitschrift für Papyrologie und Epigraphik, Bonn

Mariusz Mielczarek ORCID 0000-0002-2476-270X Institute of Archaeology and Ethnology Polish Academy of Sciences Łódź Department mielczmar@o2.pl 